\title{
Paso de contraste hacia la vena ilíaca durante uretrografia
}

\author{
Menéndez López V, Carro Rubias C, De Paz Cruz L, García Serrado S, García López F.
}

Servicio de Urología. Hospital General Universitario de Elche. Alicante.

Actas Urol Esp 2006; 30 (4): 429

$\mathrm{V}$ arón de 45 años, con sospecha de estenosis uretral, que presentó uretrorragia importante tras la realización de una uretrografía retrógrada. Se observa la opacificación del cuerpo esponjoso, el plexo de Santorini y las venas ilíacas (Fig 1).

Dra. V. Menéndez López

E-mail: violetamenendez@wanadoo.es

(Trabajo recibido el 11 de Julio de 2005)

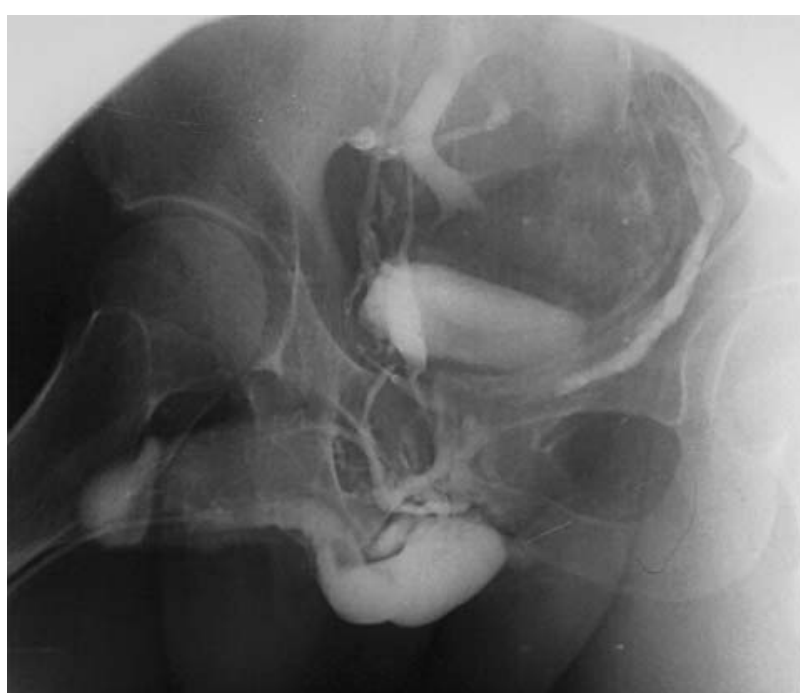

FIGURA 1 